Marek Walisch

Katedra Geografii Fizycznej

Wydział Nauk Geograficznych, Uniwersytet Łódzki

\title{
KONFERENCJA HYDROLOGICZNA „ASPEKTY BADAŃ WODY W XX I XXI WIEKU”- GDAŃSK, 18.10.2013
}

\section{HYDROLOGICAL CONFERENCE “ASPECTS OF WATER RESEARCH IN THE XX ${ }^{\mathrm{TH}}$ AND XXI ${ }^{\text {ST }}$ CENTURIES”- GDAŃSK, 18.10.2013}

18 października 2013 r. w Gdańsku odbyła się jednodniowa konferencja hydrologiczna „Aspekty badań wody w XX i XXI wieku”. Miejscem obrad był budynek Uniwersytetu Gdańskiego. Oprócz naukowego charakteru konferencji, podczas której zaprezentowano 26 referatów oraz 10 posterów pochodzących z 12 jednostek naukowych, IMGW oraz dwóch zarządów gospodarki wodnej, spotkanie poświęcone było nieżyjącym Profesorom wywodzącym się z Katedry Hydrologii Uniwersytetu Gdańskiego - Profesorowi dr hab. Janowi Drwalowi oraz Profesorowi UG dr hab. Robertowi Bogdanowiczowi. Na początku porannej sesji prof. UG dr hab. Roman Cieśliński zaprezentował sylwetki naukowe obu naukowców. Po oficjalnej części nie zabrakło jednak osobistych wspomnień, dzięki którym postacie obu Profesorów stały się dużo bliższe tym uczestnikom konferencji, którzy nie mieli sposobności osobistego poznania obu naukowców. Do wspominkowej części chętnie przyłączyli się wszyscy z różnych ośrodków naukowych, którzy współpracowali naukowo $\mathrm{z}$ obydwoma Profesorami i znali ich osobiście.

Podczas pierwszej sesji pojawiły się trzy referaty zamawiane o charakterze przekrojowym. Ich prelegenci mieli zarezerwowany nieco dłuższy czas na zaprezentowanie swych wyników. Prof. dr hab. Joanna Pociask-Karteczka z ośrodka krakowskiego dokonała podsumowania wieloaspektowych badań hydrologicznych prowadzonych w Tatrach, skupiając się na charakterystyce obiegu wody $\mathrm{w}$ tym regionie. Zaprezentowane wyniki badań potwierdzają istotne różnice pomiędzy północnymi i południowymi stokami grzbietu 
tatrzańskiego w nawiązaniu do wszystkich faz obiegu wody. Prof. dr hab. Adam Choiński z ośrodka poznańskiego zaprezentował obszerne wyniki badań nad zanikiem jezior w północnej Polsce, próbując m.in. odpowiedzieć na pytania, jak intensywne jest tempo zaniku jezior, od kiedy datuje się nagłe przyspieszenie tego procesu oraz jaki jest udział człowieka w tym procesie. W trzecim referacie, autorstwa prof. dr hab. Małgorzaty Gutry-Koryckiej z ośrodka warszawskiego, została zaprezentowana rola metodyki kartowania hydrograficznego w badaniach hydrologicznych.

Kolejna sesja została poprzedzona wystąpieniem pracowników firm, które brały udział w sponsorowaniu konferencji - OTT, Smart, OMC Envag oraz Centralnego Ośrodka Żeglarskiego w Trzebieży. Następnie pojawiły się właściwe referaty, nawiązujące swą tematyką badawczą do różnych aspektów hydrologicznych.

Jednym z wątków badawczych, który przeplatał się we wszystkich pozostałych sesjach konferencji, były zagadnienia jakości i chemizmu wód powierzchniowych: zbiorników retencyjnych, rzek, oczek zagłębień bezodpływowych, wód podziemnych oraz źródeł. W tej części najwięcej rezultatów swoich badań zaprezentowali pracownicy Uniwersytetu Łódzkiego, stanowiące efekt wieloletniej współpracy Wydziału Chemii oraz Wydziału Nauk Geograficznych, jak i Uniwersytetu im. Adama Mickiewicza w Poznaniu. Zagadnienia badawcze pierwszego ośrodka koncentrowały się wokół chemizmu wód Zbiornika Jeziorsko oraz Zbiornika Sulejowskiego, który ponad 10 lat temu przestał pełnić rolę rezerwuaru wodnego dla aglomeracji łódzkiej. Tym samym stan sanitarny tego zbiornika nie odgrywa już dla mieszkańców Łodzi jako konsumentów wody pitnej kluczowej roli, ale wciąż jest niezmiernie istotny dla mieszkańców całego regionu, korzystających z jego plaż i przystani wodnych, którzy traktują ten akwen jako obiekt turystyczny. Paradoksalnie, najgorszy stan czystości wód zbiornika został stwierdzony w zatoce w Bronisławowie, w pobliżu nieczynnego ujęcia wody pitnej dla Łodzi. Seria tych badań była przypuszczalnie ostatnią sposobnością do analizy jakości wód zbiornika przed jego opróżnieniem w celu kompleksowego oczyszczenia dna. Inny zespół badawczy skoncentrował się nad jakością ważnego cieku Parku Krajobrazowego Wzniesień Łódzkich jakim jest Mrożyca, w której m.in. stwierdzono niekorzystny wpływ zrzutów wód z oczyszczalni ścieków w Brzezinach na stan jej czystości. Charakterystyka parametrów fizyko-chemicznych 12 źródeł Wielkopolskiego Parku Narodowego, zaprezentowana przez ośrodek poznański, wykazała, że źródła te są co prawda związane $\mathrm{z}$ podobnym środowiskiem hydrogeologicznym, lecz zaznaczają się między nimi duże różnice w chemizmie ze względu na dopływ zanieczyszczeń. Inny autor $\mathrm{z}$ tego samego ośrodka uniwersyteckiego przeanalizował chemizm wód oczek wytopiskowych zagłębień bezodpływowych dorzecza Parsęty, wydzielając zasadniczo ich trzy grupy pod względem składu chemicznego. $\mathrm{Z}$ kolei chemizm wód podziemnych tych zagłębień potwierdza występowanie wód typowych dla pojeziernej strefy młodoglacjalnej. Teoretyczne podstawy 
szacowania zmian chemizmu wód akwenu przytoczyli pracownicy ośrodka gdańskiego, rozważający wpływ powierzchni makrofitów oraz zanurzonych ciał stałych o różnej hydrofobowości na jakość wody i procesy w niej zachodzące. Z ośrodka białostockiego napłynęły wyniki badań przekształceń cech fizyczno-chemicznych wody w strefach ekotonowych (łączących wody podziemne i powierzchniowe) w źródliskach i małych rzekach Puszczy Knyszyńskiej i Białegostoku oraz źródłach, rzekach i jeziorach Suwalskiego Parku Krajobrazowego. Co istotne, zaobserwowano olbrzymie różnice wartości parametrów fizyczno-chemicznych pomiędzy wodami podziemnymi i powierzchniowymi, jak i w obrębie analizowanych obiektów hydrograficznych Suwalszczyzny. Problem wynikający z wpływu antropopresji na jakość wód powierzchniowych Górnego Śląska został opracowany na przykładzie stężenia kationowych surfaktantów Kłodnicy przez zespół badawczy reprezentujący ośrodek gdański i sosnowiecki.

Drugą grupą tematyczną, która znalazła się w zainteresowaniach badawczych prelegentów, były zagadnienia limnologiczne. Pomijając obszerne wystąpienie prof. dr hab. Adama Choińskiego w sesji początkowej, do tej tematyki nawiązali naukowcy z ośrodków IMGW oddziału wrocławskiego i warszawskiego, Uniwersytetu Gdańskiego oraz Politechniki Koszalińskiej. Najbardziej przekrojowym i wszechstronnym wystąpieniem była prezentacja prof. UG, dr hab. Elżbiety Bajkiewicz-Grabowskiej, dotycząca typologii hydrologicznej oczek pojeziernych, które zostały podzielone według wybranych kategorii hydrograficznych. Jak się okazuje, nie wszystkie analizowane oczka pojezierne są związane $\mathrm{z}$ genezą wytopiskową. Monitoring poziomu wód przymorskiego jeziora Jamno, w oparciu o automatyczne stacje pomiarowe, prowadzony przez ośrodek koszaliński, został rozpoczęty przed planowanymi inwestycjami w tym akwenie, mającymi przeciwdziałać ewentualnej powodzi m.in. na skutek podnoszenia się poziomu wód Bałtyku oraz samego jeziora. Bardziej teoretyczne rozważania pojawiły się $\mathrm{w}$ wystąpieniu pracowników IMGW, którzy ukazali aspekt badań limnologicznych w Państwowej Służbie Hydrologiczno-Meteorologicznej, przedstawiając historię tej instytucji i jej wkład w badania limnologiczne prowadzone w ramach jej kompetencji.

Pojawiły się również referaty bezpośrednio mówiące o zjawiskach potamologicznych. Prof. dr hab. Alfred Kaniecki z ośrodka poznańskiego przedstawił bardzo ciekawą rekonstrukcję XIX-wiecznych powodzi w Poznaniu i Nizinie Wielkopolskiej, wywołanych silnymi wezbraniami Warty wraz z jej dopływami, którą oparł na podstawie obserwacji wodowskazowych oraz o dane znajdujące się $\mathrm{w}$ opracowaniach tekstowych. Prof. dr hab. Jan Kirviel z Białorusi, reprezentujący obecnie ośrodek słupski, zaprezentował przekrojowy referat dotyczący regulacji odpływu rzek Białorusi przez sztuczne zbiorniki. W finale 
rozważań profesor zwrócił uwagę, że na obszarze Białorusi do potencjalnego zagospodarowania jest jeszcze ponad $10 \%$ przepływu rzecznego, co mogłoby skutkować kilkukrotnym wzrostem liczby zbiorników retencyjnych.

Referaty o charakterze oceanologicznym powstały, jak przystało, na Uniwersytecie Gdańskim oraz w Wyższej Szkole Morskiej w Gdyni. Z pierwszego ośrodka pochodzą badania nad zmiennością czasową rocznych maksymalnych poziomów morza w Gdańsku od lat 80. XIX w. Szczegółowo omówiono wybrane przypadki ekstremalnych wezbrań sztormowych $\mathrm{w}$ tym mieście. Z drugiego zaś ośrodka wywodzi się referat o tematyce klimatyczno-oceanicznej, w którym autor zaprezentował wpływ temperatury wody Morza Norweskiego na wybrane wskaźniki hydroklimatyczne basenu Morza Bałtyckiego.

$\mathrm{Na}$ konferencji pojawiły się również rozważania nawiązujące do tej składowej bilansu wody, która znajduje się na wejściu do systemu, czyli do opadów atmosferycznych. W ośrodku gdańskim powstał referat, który scharakteryzował zmienność opadów atmosferycznych w delcie Wisły w wieloleciu 1961-1990 w świetle norm opadowych. M.in. dla jednego z posterunków opadowych wykazano, że okresy suche i bardzo suche występują bezpośrednio przed lub po okresach wilgotnych lub bardzo wilgotnych. W tym samym ośrodku uniwersyteckim powstał referat prof. dr hab. Mirosława Miętusa analizujący wybrane przypadki opadów intensywnych na obszarze Polski wraz z ich konsekwencjami. Autor starał się ocenić ewentualne ryzyko zwiększenia częstości występowania ekstremalnych zjawisk opadowych na obszarze Polski, a co za tym idzie - ocenić skalę potencjalnego zagrożenia.

Pozostałe nieliczne referaty nie mieszczą się w wyżej wymienionych kategoriach badawczych. Jeden $\mathrm{z}$ nich, pochodzący z ośrodka gdańskiego, stoi na pograniczu badań hydrologicznych i geomorfologicznych. Autor przedstawił ciekawe wyniki badań zestawiające wpływ spiętrzeń sztormowych na rozwój barier piaszczystych na przykładzie Mierzei Karwieńskiej. Okazuje się, że materiał wyrzucany podczas silnych spiętrzeń sztormowych stanowi istotną część budowy niskich mierzei południowego Bałtyku. Inni autorzy wywodzący się z tego samego ośrodka (oraz reprezentujący firmę GeoTim PU) podjęli próbę przedstawienia wybranych problemów hydrologicznych $\mathrm{w}$ prowadzeniu prac budowlanych. Wybrane przykłady zostały opracowane na podstawie doświadczenia autorów zebranego w czasie realizacji różnych inwestycji. Inny referat, z ośrodka poznańskiego, omawiał kwestie zastosowania modelu WetSpass w estymacji obszarowej składowych bilansu wodnego zlewni. Rozważania oparto na przykładach zlewni środkowej części Niziny Wielkopolskiej, bazując na technikach GIS.

Z tematyką posterów można się było zapoznać podczas przerw kawowych. Nie odbiegała ona swym charakterem od wyżej wymienionych grup tematycznych. Ich autorzy reprezentowali te same ośrodki naukowe co prelegenci. 
Późnym popołudniem konferencja dobiegła końca. Na jej zakończenie, poniekąd w podsumowaniu, prof. dr hab. Alfred Kaniecki podziękował gospodarzom za organizację zjazdu podkreślając jednocześnie, że spotkanie to było bardzo owocne, a niemała część referatów dotykała newralgicznych i bieżących problemów hydrologicznych. Zaznaczył też $\mathrm{z}$ żalem, że brak przeznaczonego czasu na dyskusje merytoryczne był w jego ocenie pewnym mankamentem całej konferencji, która $\mathrm{z}$ założenia jako jednodniowe spotkanie nie mogła zaoferować prelegentom czasu zarezerwowanego na tę formę aktywności.

Tym samym chciałbym się dołączyć do podziękowań za zorganizowanie bardzo ciekawej konferencji naukowej, a przede wszystkim podziękować gospodarzom za bardzo miłą i ciepłą atmosferę, jaka panowała na sali obrad, jak i w kuluarach.

\section{LITERATURA}

Cieśliński R., Jereczek-Korzeniewska K. (red.), 2013, Aspekty badań wody w XX i XXI wieku, Streszczenia artykułów z konferencji hydrologicznej, 18.10.2013, Uniwersytet Gdański, Gdańsk, ss. 68. 